\title{
KAJIAN AWAL REALITAS DAN PRAKTIK PEMBELAJARAN BAHASA ARAB MADRASAH MINORITAS MUSLIM PAPUA BARAT
}

\author{
Ismail Suardi Wekke*, Agung Muttaqien** \\ *Sekolah Tinggi Agama Islam Negeri (STAIN) Sorong \\ **Universitas Islam Negeri (UIN) Maulana Malik Ibrahim Malang \\ Email: iswekke@gmail.com
}

\begin{abstract}
ABSTRAK
Pembelajaran bahasa Arab terkait dengan lingkungan masing-masing. pada hal umum terdapat kesamaan, begitu juga dalam soal yang detail terdapat perbedaan yang secara khusus hanya terjadi dalam kondisi tertentu saja. Keadaan ini perlu mendapatkan perhatian sehingga memungkinkan akselerasi pembelajaran bahasa Arab walaupun terdapat di minoritas muslim. Makalah ini bertujuan untuk mengidentifikasi realitas dan praktik pembelajaran bahasa Arab minoritas muslim Papua Barat. Secara khusus mengkaji madrasah di Kota Sorong. Wawancara mendalam dan pengamatan dilaksanakan sebagai bagian dari teknik pengumpulan data. Pengecekan keabsahan data dilakukan dengan triangulasi data dan diskusi terarah dalam tiga kali pertemuan. Penelitian ini menunjukkan dinamika pembelajaran bahasa Arab di wilayah minoritas muslim. Beberapa tantangan dan sekaligus peluang yang menjadi daya dukung pembelajaran. Sementara itu, keterbatasan diatasi dengan melakukan kolaborasi dan kerjasama kelembagaan sehingga masing-masing institusi dapat saling mendukung antara satu dengan yang lain. Makalah ini mengelaborasi pembelajaran bahasa Arab bukan saja tentang kemampuan berbahasa tetapi juga berkaitan dengan spirit beragama.
\end{abstract}

Kata kunci: madrasah, minoritas muslim, kerjasama, realitas, tantangan

\section{PENDAHULUAN}

Walaupun bahasa Arab salah satu bagian utama dari tradisi dunia Islam namun tetap saja kesulitan demi kesulitan dalam belajar bahasa Arab senantiasa mengemuka. Begitu juga dengan pesan-pesan ayat al-Quran senantiasa yang memberikan isyarat bagaimana bahasa Arab menjadi sebuah alat yag paralal dengan keberadaan al-Quran itu sendiri (Yusuf (12) ayat 2). Inovasi pembelajaran seiring dengan kesulitan ini juga tumbuh untuk menjawab tantangan problematika tersebut. Namun semua itu belum mendapatkan hasil yang diharapkan. Ganjalan pertama, pembelajaran bahasa Arab senantiasa dipandang sebagai bagian dari belajar agama semata-mata. Sehingga ketika belajar bahasa Arab, anggapan yang muncul adalah itu belajar agama. Padahal, sebagai bahasa yang juga digunakan dalam komunikasi antarbangsa, bahasa Arab menempati posisi yang tidak kalah pentingnya dibanding dengan bahasa bangsa lainnya. Untuk sekadar menyebut contoh, bahasa Inggris. Penggunaan bahasa Arab juga meluas mulai dari Maroko dampai ke Jeddah. Belum lagi hubungan perdagangan antara masyarakat Arab dengan masyarakat lainnya. Ini bermakna, tidak saja dalam urusan yang berhubungan dengan akhirat semata. Tetapi juga keperluan duniawi senantiasa berhubungan dengan bahasa Arab juga.

Sejak terbukanya akses ke dunia Arab, maka kawasan China, India bahkan sampai di Asia Tenggara mengalami perjumpaan dengan kebudayaan Arab. Tidak saja kontak kebudayaan tetapi 
menjangkau pelbagai aspek kehidupan yang lebih luas. Termasuk di dalamnya elemen bahasa Arab. Sehingga ini dapat menjadi sebuah argumen bagaimana luasnya pengaruh bahasa Arab termasuk pula dalam urusan perniagaan. Di era pasar bebas sekarang ini, perdagangan dunia Arab menjadi bagian sentral perekonomian dunia. Tanpa menggarap pasar Arab, maka sebuah perusahaan dapat saja tidak akan mendapatkan keuntungan yang maksimal. Sebaliknya ketika perusahaan menjadikan penetrasi pasar Arab sebagai bagian dari portofolio, maka keutungan dan laba senantiasa akan mengiringi proses tersebut. Dengan demikian, bahasa Arab menjadi penting untuk dipelajari. Tidak semata-mata dalam urusan keagamaan, tetapi melampaui batas-batas urusan keislaman. Bahasa Arab menjadi bagian dari kepentingan komunikasi sebagaimana bahasa bangsa lainnya.

Narasi makalah ini dimulai dari gambaran tentang betapa bahasa Arab hanya dipandang sebagai bahasa dalam urusan ibadah. Padahal, menguasai bahasa Arab tidak akan mendatangkan kerugian dalam dunia bisnis kontemporer. Sehingga belajar bahasa Arab harus didudukkan dalam konteks perkembangan dunia mutakhir. Kapasitas individu kemudian dapat tetap bertahan dalam kompetensi dunia menjadi salah satu faktor yang perlu diperhatikan. Dalam bagian kapasitas itu, bahasa menjadi keahlian yang perlu dikuasai (Yovita, 2004). Komunikasi verbal menjadi alat utama manusia dalam menyampaikan gagasan dan ide kepada pihak lain. ini juga berarti bahwa bahasa menjadi bagian yang dominan dalam hubungan komunikasi dengan masyarakat dunia lainnya. Dengan demikian, bahasa Arab menemukan kontekstualisasinya. Tidak saja dalam posisi sebagai bahasa yang digunakan untuk berkomunikasi dengan dunia Islam dan seluruh atributnya, tetapi juga untuk menjalin hubungan dengan masyarakat yang Arab lainnya. Secara politispun, dunia Arab menjadi bagian dari stabilitas politik dan juga penentu keamanan dunia.

Semangat dan optimisme dalam mencapai keterampilan berbahasa merupakan faktor yang menjadi pilar pembelajaran. Dalam kajian Wanlabeh (2012) dikemukakan bahwa peserta didik yang optimis memiliki kemampuan untuk mengeksplorasi dimensi belajar dalam pelbagai kesempatan (Wanlabeh, 2012). Ini diilustrasikan dengan adanya dua orang siswa dengan kemampuan akademik yang sama. Dengan adanya optimisme di salah satu siswa, maka siswa yang paling optimis akan mempunyai kemampuan yang lebih tinggi dibandingkan dengan siswa yang pesimis. Mereka dapat mengontrol kehidupan dan dapat melakukan kegiatan-kegiatan yang lebih berguna. Serta berusaha meningkatkan derajat optimismenya dari waktu ke waktu (Moore:1998). Hasil penelitian Yates juga menunjukkan bahwa optimisme dan prestasi akademik saling berhubungan secara signifikan (Yates, 2000). Dengan demikian, optimisme merupakan bagian dari bidang kehidupan individu. Dalam posisi ini, maka perlu ditumbuhkembangkan sikap optimisme dalam proses belajar. Sehingga hasil yang dicapai dalam usaha belajar pada mata pelajaran dapat dicapai secara maksimal.

Kondisi yang terjadi dalam sebuah pembelajaran bahasa Arab tidak dapat dilepaskan dari metode yang menjadi nafas sebagai penggerak pelaksanaanya. Al-Khuli memberikan pandangan dalam hal ini bahwa dimesi pikiran yang berpengaruh pada perilaku dalam diri dan antarmanusia (Al-Khuli, 1981). Ini berarti bahwa keberadaan sebuah metode pembelajaran berkaitan langsung 
dengan perilaku ataupun tindakan yang dilaksanakan selama proses pembelajaran berlangsung. Bagaimana hasil yang dicapai tidak dapat dilepaskan dari aspek perilaku dalam melibatkan ranah pembelajaran yang ada. Sementara itu, langkah-lankah operasional yang dilaksanakan akan memberikan dampak bagi penguasaan bahasa. Tidak saja berjalan di dalam kelas tetapi akan memberikan pengaruh pada kondisi pembelajaran bahasa secara khusus. Kebulatan atas sebuah metodologi yang digunakan juga berkaitan dengan komponen yang lain.

Bahasa Arab sebagai mata pelajaran tidak dapat melepaskan diri dari mata pelajaran lain yang berada dalam struktur kurikulum. Keterkaitan ini merupakan bagian dari tujuan yang lebih komprehensif, yaitu pendidikan yang menjadi sarana pembentukan dalam seluruh bidang kehidupan. Sehingga ini berarti bahwa pendidikan menyiapkan peserta didik untuk menjalani kehidupan yang lebih luas. Tidak saja terbatas dengan ruang kelas dalam batasan tembok. Bahasa sejatinya merupakan pemahaman penggunaan kosakata. Sehingga tidak saja kelas merupakan prosesi dalam menuntaskan kurikulum, tetapi lebih dari itu. Pembentukan konsepsi dan perilaku justru tergambar dari kurikulum, kemudian di kelas menjadi tindak lanjut operasional untuk mencapai tujuan yang telah ditetapkan dalam kurikulum (Yamin, 2010).

Pendidikan di madrasah sebagai tahap awal untuk mengembangkan kelanjutan pendidikan di masa yang akan datang. Jika diperinci, jika pendidikan madrasah dibangun dengan sebuah kesungguhan yang terbukti dengan kerapian, maka ini akan meletakkan dasar bagi pola pendidikan secara makro. Hanya saja, pendidikan madrasah masih berada dalam bentuk formalitas belaka. Kepercayaan untuk memadukan ini masih dalam kerangka konseptual. Padahal, pendidikan madrasah yang dijalankan berbasis pada pesantren menjadi sebuah bukti betapa madrasah sesungguhnya mengadaptasikan diri dan mengakomodasikan kepentingan masyarakat. Sehingga dapat dimaknai bahwa madrasah merupakan soko guru pengembangan masyarakat yang justru berakar dari tradisi masyarakat itu sendiri. Dapat saja, pengalaman yang didapatkan dari lapangan menjadi sebuah makna yang didapatkan guru dari proses di kelas. Ini berarti dengan melepaskan semua prasangka teoritis, esensi dari pengalaman itu kemudian didiskusikan untuk diverifikasi (Boeree, 2008). Sehingga makna yang ditemukan dapat menjadi sebuah penjelasan mengenai realitas.

Praktik pembelajaran bahasa secara modern diperkenalkan dengan pendirian pesantren modern sebagai upaya untuk melakukan terobosan pembelajaran bahasa yang dalam kurun waktu itu stagnan dan hanya semata-mata digunakan sebatas dalam kemampuan non-aktif (Wekke, 2015). Sementara tuntutan, tidak hanya semata-mata hanya pada kemampuan membaca dan memahami teks keagamaan saja. Seiring dengan perkembangan dan tuntutan keadaan, kemampuan komunikatif dengan mendengar dan bertutur juga senantiasa menjadi keperluan. Pada saat yang sama bukan berarti kebutuhan untuk membaca dan memahami teks yang berbasis pada ajaran keagamaan kemudian memudar. Kesemuanya bergantung kepada keperluan pembelajaran bahasa Arab yang disasarkan. Untuk itu, adaptasi metode disesuaikan semata-mata kepada pola pembelajaran yang hendak dicapai. Sebuah model yang diterapkan lembaga tertentu tidaklah menjadi satu-satunya rujukan. 


\section{REALITAS PEMBELAJARAN BAHASA ARAB}

Masalah utama dalam pembelajaran bahasa adalah transformasi penguasaan kebahasaan yang tidak sebatas internal tetapi mampu terbentuk dalam keterampilan yang fungsional. Kemampuan menganalisis tata bahasa tidak lebih penting daripada ekspresi dalam bahasa itu sendiri. Pembelajaran bahasa yang berlangsung dalam tradisi pesantren Indonesia menjadikan bahasa Arab dalam bentuk kajian tata bahasa dan terjemahan. Dalam pola pembelajaran seperti ini, latihan untuk mengekpresikan keterampilan berbahasa tidak akan terwujud dari pertemuan ke pertemuan. Sebaliknya hanya akan menjadi sebuah proses untuk menyerap secara kognitif informasi tentang bahasa. Penguasaan bahasa terbatas pada gramatikal tanpa mampu digunakan dalam ekspresi. Kemampuan analisis pada tata bahasa itulah yang akhirnya berkembang dan tidak relevan untuk pencapaian tujuan pembelajaran bahasa yang akan digunakan dalam interaksi

keseharian. Berbeda jikalau itu untuk kemampuan keilmuan dan kecendekiawan dalam beragama. Maka, secara khusus tujuan pembelajaran akan menentukan metode dan segala atribut yang melingkupinya berkenaan dengan pembelajaran yang akan dilaksanakan. Ketidaktepatan dalam memilih metode yang sesuai dengan tujuan dan materi belajar akan menjadikan proses belajar menjadi tidak bermakna.

Kemampuan kebahasaan dapat distimulasi salah satunya berawal dari metode pembelajaran yang tepat. Tanpa itu, maka materi pelajaran akan sia-sia belaka. Terkadang seorang tenaga pengajar lebih fokus kepada materi belajar tanpa memikirkan bagaimana caranya untuk mentransfer kemampuan itu kepada peserta didik. Sehingga yang terjadi hanya sematamata pembahasan dan dilakukan dengan satu arah. Akibatnya, peserta didik mengalami kebosanan dan daya serap yang sangat rendah. Sehingga materi tidak lagi dikuasai bahkan dapat saja berubah menjadi sebuah ketidaksuakaan. Keefektifan dalam mengkomunikasi materi akan menjadi daya dukung dalam proses belajar di kelas. Tanpa itu, maka keberadaan kelas akan siasia saja. Sejatinya, kelas akan menjadi sarana dalam merubah ketidakbisaan menjadi sebuah kompetensi. Suasana yang kondusif harus diciptakan dalam kelas agar supaya apa yang dijadikan sebagai pokok bahasan dapat juga dikuasai oleh siswa.

Kata kunci dari semua masalah ini adalah soal metode belaka. Ketepatan atas pilihan sebuah metode berkaitan dengan materi dapat menjadi jalan maksimalnya hasil belajar yang dapat dicapai. Dengan keragaman metode dan aktivitas yang komprehensif di kelas, akan menjadikan pembelajaran yang berlangsung justru menemukan makna yang tepat. Materi bahasa Arab yang diajarkan tidak saja menjadi sebuah mata pelajaran, tetapi justru menjadi jangkar bagi pemahaman keagamaan secara menyeluruh. Dengan dikuasainya bahasa Arab, ini akan meletakkan dasar bagi penguasaan materi yang lain. sehingga dengan menguasai bahasa Arab menjadi modal awal bagi penguasaan studi keislaman secara mendalam. Maka, diperlukan sebuah inovasi bagaimana pembelajaran bahasa Arab dapat berjalan dengan mengusung makna ini secara luas. Guru dan manajemen madrasah perlu memilih kesesuaian antara metode yang diterapkan dengan tujuan awal pembelajaran. Setiap materi berbeda, sehingga keseragaman antara materi yang satu dengan lainnya tidak diperlukan. 


\section{ISU DAN DISKURSUS PEMBELAJARAN BAHASA ARAB}

Keterampilan berbahasa asing merupakan bagian dari aktivitas pendidikan mutakhir. Dimana perjumpaan dengan kebudayaan lain menjadi sebuah keperluan untuk pengembangan ilmu pengetahuan, seni, budaya. Dalam skala yang lebih luas, membangun sebuah peradaban saat ini tidak lagi dapat dilakukan secara sendiri. Tetapi sudah memerlukan kehadiran dan bantuan bangsa lain untuk turut memperkaya dan bersama-sama melakukan inovasi. Dengan bahasa asinglah sebagai alat dalam menjalin komunikasi. Namun tidak berarti bahwa ini dalam rangka menggeser kedudukan dan fungsi bahasa nasional maupun bahasa daerah. Dengan bahasa asing menjadi alat dalam penyampaian gagasan, ide dan pokok pikiran sehingga bangsa lain dapat memahami situasi dan keadaan komunitas kita.

Dalam kaitan ini, menjadi sebuah keperluan untuk mewujudkan pembelajaran bahasa dalam mencapai keterampilan yang maksimal. Hanya saja, madrasah belum mencapai tujuan pembelajaran yang ditetapkan. Bahasa Arab baru sebatas menjadi mata pelajaran yang harus dituntaskan di akhir semester. Sementara penguasaan yang berkelanjutan tidak menjadi sebuah target secara khusus. Padahal. Bahasa Arab bukanlah hanya karena menjadi bagian dari muatan kurikulum. Tetapi lebih dari itu, melampaui urusan materi kurikulum. Dengan hadirnya pembelajaran yang mampu menghasilkan lulusan sesuai dengan kebutuhan lingkungan, maka pembelajaran berarti sudah menjadi sarana untuk memberikan penguatan keterampilan. Tidak sekadar menjadi rutinitas pendidikan belaka.

Sebuah pertanyaan yang penting justru berada di awal ketika belajar bahasa, "apa yang akan dicapai di akhir pembelajaran?". Maka, menetapkan tujuan pembelajaran menjadi sebuah keperluan. Tanpa itu, maka arah belajar tidak dapat ditetapkan. Demikian juga dengan tidak adanya objektif yang akan dicapai menjadi setiap pertemuan ke pertemuan tidak akan terhubung dan justru kehilangan makna. Dalam posisi ini, maka jawaban akan tujuan belajar bahasa sudah disediakan sebelum semuanya dimulai. Bukan di bagian tengah, atau justru berada di bagian yang paling akhir. Sebaliknya harus sudah ditetapkan karena akan memandu penentuan materi dan segala atribut yang menjadi konsekwensi dari segala unsur yang ada. Dengan demikian, akan terbentuk pemahaman yang utuh tentang semua aspek yang berkaitan untuk mendukung sehingga hasil belajar dapat dicapai bersama. Tidak saja oleh murid, tetapi juga oleh guru sebagai fasilitator.

Bahasa Arab menjadi perhatian dalam pendidikan Islam karena posisinya sebagai dasar dalam memahami kajian Islam lebih lanjut. Azhar Arsyad menulis dua aspek dengan judul Bahasa Arab dan Metode Pengajarannya. Buku tersebut merupakan himpunan dari makalahmakalah yang disajikan dalam beberapa kesempatan berbeda. Adapun benang merah masingmasing makalah tergambar dalam hal kajian subtansi bahasa Arab dan selanjutnya ditindaklanjuti dalam bentuk pola pengajaran (Arsyad, 2010). Hanya saja buku ini tidak secara spesifik memandu pembaca dalam menerapkan langkah demi langkah. Sementara fokus buku ini lebih kepada mengkaji bahasa Arab dalam konteks pendidikan bahasa Asing. Beberapa laporan penelitian berkenaan dengan linguistik terapan juga disajikan secara lengkap. 
Publikasi selanjutnya yang perlu ditelaah adalah Metodologi Pembelajaran Bahasa Arab karya Ahmad Izzan (2011). Buku tersebut secara khusus memberikan gambaran tentang teknik yang dapat digunakan dalam pembelajaran bahasa Arab. Diantara pembehasannya termasuk pada teknik penerjemahan dan juga teknik membuka kamus. Kedua teknik ini menjadi pelengkap dalam pembelajaran bahasa Arab yang perlu dikuasai. Keunggulan buku terletak pada aplikasi teknik yang praktis. Hanya pada tiga bab awal yang menguraikan perkembangan dan peranan bahasa Arab. Sementara bab yang tersisa secara keseluruhan menjelaskan pada teknik yang digunakan dalam proses pembelajaran. Termasuk dalam pembahasa teknik pengembangan keterampilan berbahasa. Begitu juga dengan teknik penggunaan audio visual. Sehingga buku ini menjadi sebuah terobosan yang aplikatif untuk menjalankan sebuah proses belajar mengajar bahasa Arab dalam bentuk aktivitas kelas.

Secara khusus buku yang berjudul Perencanaan Pengajaran Bahasa karya Esti Ismawati (2011) tidak ditujukan untuk pengajaran bahasa Arab. Tetapi ini mencakup pada pengajaran bahasa secara umum, tentu dapat dipergunakan juga untuk pengajaran bahasa Arab. Bab-bab yang dituliskan dalam rangkaian buku ini dimulai dari telaah tujuan pengajaran. Sehingga dapat memandu guru untuk mulai merencanakan sebuah proses belajar mengajar sejak awal. Termasuk pada bagian akhir adalah uraian penyusunan Rencana Pelaksanaan Pengajaran (RPP) yang mencontohkan pembelajaran dalam mata pelajaran bahasa Indonesia. Buku ini merupakan panduan yang dapat dijadikan pegangan untuk mengembangkan perencanaan pengajaran. Pengarang membahas dalam pola pengembangan instruksional secara lengkap. Begitu juga dengan gambaran proses pengembangan media pembelajaran. Setelah sebelumnya membahas proses penilaian dan bagaimana metode yang dipilih sesuai dengan materi yang yang akan diajarkan.

Terakhir, buku yang ditulis Acep Hermawan (2011). Kelebihan buku ini terletak pada deskripsi secara detail mengenai karakteristik. Selanjutnya dijabarkan dalam bentuk penjelasan dengan kategori keterampilan berbahasa. Pada bagian selanjutnya memaparkan pilihan metode yang dapat digunakan dalam mencapai keterampilan berbahasa yang ditargetkan. Buku ini menjadi sebuah panduan dalam mengklasifikasi bagaimana keterampilan berbahasa sekaligus mengembangkan materi bahasa Arab yang diajarkan untuk dijabarkan dalam bentuk keterampilan. Sekaligus memberikan panduan sejak awal bagaimana bahasa Arab dalam karakternya yang khas kemudian perlu diadaptasikan dalam perkembangan terkini yang berkenaan dengan metode dan juga penggunaan media yang beragam. Pembelajaran bahasa Arab juga ditempatkan sebagai komponen pembelajaran bahasa asing. Sehingga terdapat kendala dalam proses pengajaran. Untuk itu, ditawarkan beberapa solusi untuk memudahkan guru dalam menyampaikan materi belajar dan pilihan metode yang dapat digunakan.

Keberadaan buku ini menemukan relevansi dengan menempatkan pada posisi bahwa secara khusus pembelajaran bahasa Arab dengan menumpukan perhatian pada pembelajaran di madrasah belum dibahas oleh para pakar. Sehingga dengan ketiadaan literatur yang berkaitan dengan ini menjadi sebuah potensi yang dapat dikembangkan. Buku ini secara khusus dikembangkan untuk dijadikan sebagai referensi dalam pembelajaran bahasa Arab di madrasah. 
Walaupun beberapa pesantren juga menggunakan bahasa Arab sebagai kegiatan utama, hanya saja ini dibatasi dalam lingkup madrasah atau pendidikan formal. Karena keterkaitannya dengan telaah kurikulum yang ditetapkan sebagai standar minimal materi yang harus diajarkan. Secara mapan pula, hanya madrasah yang membenahi kurikulum dan seluruh perangkatnya yang ada. Sehingga pembahasan buku ini akan menghubungkan aspek-aspek itu sebagai komponen pembelajaran. Selanjutnya dalam pembahasan menggunakan teori-teori atau prinsip-prinsip yang sejalan dengan lingustik terapan seperti sosiolinguistik, psikolinguistik, dan keterpaduan dengan teori pendidikan dan pembelajaran.

Ada kendala yang melingkupi pembelajaran bahasa Arab yaitu selalu saja hanya berkaitan dengan tradisi (Graham, 1993). Padahal, pengembangan pembelajaran dapat dikemukakan untuk mencapai target pembelajaran yang berbeda dengan masa lalu. Sementara itu, interaksi kebahasaan tidak lagi pada sebatas hanya persoalan Arab fusha. Keperluan akan dialek Arab di kawasan Teluk Timur Tengah juga diperlukan untuk dikenali (Abuata \& Al-omari, 2015). Kesempatan belajar bahasa Arab juga merupakan bagian dari belajar agama (Aown, 2011). Posisi seperti ini menjadi keunggulan tersendiri. Sehingga ketika belajar bahasa Arab dapat saja diintegrasikan dengan materi keagamaan. Sekaligus sebagai kesempatan emas untuk melindungi siswa dari pemahaman keagamaan yang radikal (Giladi, 2014). Begitu pula integrasi pembelajaran dengan kebudayaan (Wekke, 2012). Untuk itu, ketika pembelajaran bahasa Arab dilaksanakan dalam konsep yang menyeluruh, akan memberikan capaian pembelajaran yang tidak hanya pada soal keterampilan berbahasa semata tetapi terintegrasi dengan kemampuan lainnya dan bahkan bisa sampai pada pembentukan kepribadian siswa.

\section{KERANGKA TEORI DAN KONSEP}

Belajar merupakan tuntutan bagi setiap individu. Hanya proses menangis dan makan yang tidak perlu dipelajari. Selebihnya, semuanya memerlukan latihan. Termasuk makan sesuai dengan etiket yang disepakati lingkungan tertentu. Begitu juga dengan kemampuan berbahasa. Tidak dilahirkan, tetapi perlu dilatihkan. Penguasannya disesuaikan dengan pertumbuhan dan perkembangan lingkungan. Hukum latihan dan hukum efek dikemukakan Thorndike dan Chunningham (1986) untuk menjelaskan fenomena ini. Dengan belajar, maka seorang individu dapat membentuk perilaku melalui latihan. Dengan berulangnya proses ini, maka potensi untuk pembentukan yang bersifat permanen dapat diwujudkan.

Dalam proses ini, diperlukan ciri dan makna belajar. Wujud utama adalah perubahan. Dari keadaan yang tidak terampil menjadi terampil. Kondisi ini bukan dalam kondisi sementara, tetapi bersifat permanen. Proses belajar menjadi penentu dalam perubahan tersebut. Walaupun tidak tampak secara langsung, proses belajar merupakan bagian pengalaman belajar. Dapat saja adanya pengaruh eksternal kemudian menjadikan pengalaman belajar tersebut menjadi lebih kuat. Pengulangan-pengulangan yang dilakukan akan semakin menjadikan pengalaman belajar menjadi sebuah keterampilan.

Dukungan sosial untuk sebuah proses belajar menjadi sebuah kebutuhan bagi siswa. Dukungan yang pertama dan utama tentunya berasal dari guru. Interaksi dalam kelas dengan 
sesama pelajar dapat diminimalkan dengan hadirnya seorang guru yang memberikan dorongan sehingga terwujud sebuah kesempatan untuk belajar dengan kondusif. Selanjutnya, faktor lingkungan menjadi daya dukung berikutnya. Lingkungan akan menjadi sebuah sumber bagi energi positif jikalau dari jaringan sosial yang ada dapat memberikan kesenangan, perhatian, penghargaan, maupun bantuan. Kondisi ini juga bermakna kehadiran seseorang dalam lingkungan yang dapat dipercaya untuk membantu, mendorong, menerima, dan menjaga individu tersebut. Maka, dalam posisi ini seorang guru menjadi motivator bagi peserta didik untuk meraih kemampuan lebih dibandingkan dengan kemampuan sebelumnya.

Proses belajar bahasa memerlukan bantuan individu lain. Di dalamnya tercakup hubungan sosial dengan orang lain. Kehidupan lingkungan yang buruk tidak dapat menjadi sarana interaksi untuk melakukan sosialisasi. Emosi, materi, dan informasi menjadi bagian yang diperoleh dari lingkungan. Keterampilan dapat diperoleh dengan adanya kesempatan untuk berlatih secara intensif serta bantuan untuk meraih sebuah hasil. Dengan berada dalam lingkungan dan bantuan pihak lain, maka hasil yang diperoleh lebih mudah untuk didapatkan ketimbang menjalaninya secara mandiri. Secara sosiologis, ini akan menjadi sebuah potensi yang kuat untuk mendukung ke arah pencapaian target belajar yang ditetapkan. Apabila dukungan sosial dari lingkungan didapatkan, maka akan memperkukuh kemampuan peserta didik.

Cronbach mendefinisikan belajar sebagai proses perubahan tingkah laku. Ini akibat dari sebuah pengalaman. Dimulai dari sebuah pengalaman, kemudian menunjukkan sebuah proses dan bagian akhir akan memunculkan sebuah perubahan tingkah laku. Dalam kaitan dengan tingkah laku ini terdapat tiga hal yang berkaitan yaitu permanen, bukan kematangan, dan usaha (Cronbach, 1963). Dari tiga komponen ini, perubahan tingkah laku berbentuk pengetahuan, kecakapan, keterampilan, pemahaman, sikap dan kebiasaan. Dalam hal perubahan tingkah laku untuk penguasaan bahasa, penguasaan komunikasi verbal merupakan kemampuan dasar yang utama. Dengan adanya proses belajar, maka seorang siswa dari tidak mampu menggunakan bahasa tersebut, menjadi terampil dalam mengkomunikasikan ide dengan bahasa yang baru dikuasainya. Bahkan dalam bermimpi sekalipun sudah menggunakan bahasa yang dipelajarinya. Ini menunjukkan bahwa kemampuan kebahasaan tidak dapat dilakukan secara instan. Melainkan ada tahapan-tahapan yang harus dilakukan untuk mendapatkan keterampilan yang paripurna.

Belajar bahasa kedua memerlukan usaha yang berkesinambungan dan bukan ditempuh dalam waktu yang singkat. Hanya saja dengan adanya metode yang mutakhir serta penggunaan media pembelajaran yang tepat akan menjadikan proses belajar sebagai bentuk yang sederhana. Tidak lagi sekompleks yang terjadi di masa lalu. Begitu juga dengan pemahaman yang sudah didapatkan pada bahasa pertama menjadikan bahasa kedua selalu merujuk kepada bahasa ibu yang sudah dikuasai terlebih dahulu. Proses pengajaran di sini hadir bukan untuk mempermudah proses belajar tersebut. Tetapi kehadirannya justru menjadi fasilitator untuk memberikan pemahaman yang komprehensif dalam bentuknya yang kompleks. Di samping itu, bahasa juga memerlukan konteks. Unsur budaya dan linguistik yang menjadi bagian bahasa menuntut bagaimana bahasa itu digunakan dalam lingkungannya. Tanpa itu, maka bahasa akan kehilangan relevansinya. 
Teori belajar kognitif yang digagas Piaget relevan dalam kaitan dengan kegiatan mempelajari bahasa. Pengembangan teori tersebut ditindaklanjuti oleh Gagne (1989) dengan teori pemrosesan informasi. Ketika siswa memperoleh informasi dalam bentuk pakem atau aturan kebahasaan, maka informasi tersebut diproses. Selanjutnya diterapkan dalam ujaran yang digunakan. Hanya saja, ketika konsep ini digunakan, diperlukan pula faktor pengembangan dalam lingkungan tersebut. Ini pada gilirannya akan menjadi akumulasi dari perkembangan pembelajaran dari waktu ke waktu. Dimulai dari informasi awal kemudian berkembang menjadi penerimaan informasi yang pada akhirnya tercermin sebagai hasil belajar. Terjadi pula proses internal dan eksternal, dari keduanya menghasilkan sebuah kondisi dimana dapat menjadi capaian tersendiri. Bahkan, dalam kondisi yang sama setiap individu akan mendapatkan hasil yang berbeda antara yang satu dengan yang lainnya.

Dalam kaitan dengan pendidikan formal, belajar bahasa merupakan aktivitas yang dapat ditempuh dalam pelbagai bentuk. Termasuk salah satu pilihan yang dapat dilakukan adalah pendidikan formal. Begitu pula dengan kurikulum pendidikan yang menjadikan pendidikan bahasa sebagai bagian utama dari kurikulum nasional. Untuk itu, pembelajaran bahasa merupakan sebuah keperluan yang mesti disosialisasikan sekaligus dikuasai oleh seorang guru. Secara khusus, kajian ini menumpukan pada pendidikan bahasa dengan aktivitas formal. Sehingga beberapa langkah dalam mewujudkan rangkaian itu diperlukan dalam mencapai tujuan akhir proses pembelajaran. Dimana tidak saja berkaitan dengan keterampilan tetapi melibatkan pula administrasi pendidikan. Dimana ada keterkaitan antara penyelenggaraan pendidikan dengan dinamika politik yang berkembang.

Madrasah di Papua Barat, khasnya di Kota Sorong memiliki dinamika tersendiri. Keislaman yang terbangun dalam tradisi dan keberagaman (Wekke, 2013). Dimana akses pembelajaran tidak lagi menjadi masalah utama. Sehingga interaksi yang memadai, isu pendidikan terkini selalu dapat diakselerasi. Aplikasi pembelajaran mutakhir juga perlu diiplementasikan (Yusuf \& Suardi, 2015). Termasuk kemampuan manajerial pendidikan yang menjadi keperluan. Pendidikan Islam dalam skala yang luas di Indonesia memiliki kesempatan untuk berkembang (Roslan Mohd Nor \& Malim, 2014). Tidak lagi sebatas pada orientasi Timur Tengah semata (Mourad \& El Karanshawy, 2013). Dengan demikian, pengembangan peendidikan Islam dengan bahasa Arab sebagai pilarnya perlu diakselerasi sesuai dengan kondisi masing-masing lingkungan madrasah.

\section{PENUTUP}

Kajian awal menunjukkan bahwa pembelajaran bahasa Arab tidak beranjak dari diskursus tentang metode dan runutan hanya seputar pada aspek kelas semata. Padahal, pembelajaran bahasa Arab sesungguhnya memiliki aspek pengembangan yang tak kalah luasnya dengan kelas semata. Untuk itu, sebuah langkah diperlukan untuk membangun kesefahaman dalam rangkaian pengembangan pembelajaran dalam pelbagai aspek. Bahasa Arab memiliki keunggulan tersendiri dimana secara teologis memiliki landasan yang kukuh bahkan secara khusus dalam Al-Quran mengabadikan pesan-pesan tentang bahasa Arab. 
Dalam kaitan dengan madrasah di minoritas muslim, maka pembelajaran bahasa Arab dapat dikembangkan dengan memperhatikan lingkungan. Beberapa hal yang menjadi kendala juga diantaranya adalah keperluan tentang tenaga pengajar yang akan mendampingi siswa dalam belajar. Sementara dalam kaitan dengan materi pembelajaran dapat dikembangkan dengan memaksimalkan penggunaan teknologi informasi. Kajian ini merupakan tinjauan awal dalam mencermati pembelajaran bahasa Arab di minoritas muslim, Papua Barat. Sehingga diperlukan identifikasi pada tahapan selanjutnya untuk menganalisis kembali realitas dan praktik yang berkembang di madrasah.

\section{DAFTAR PUSTAKA}

Abuata, B., \& Al-omari, A. (2015). A rule-based stemmer for Arabic Gulf dialect. Journal of King Saud University - Computer and Information Sciences, 27(2), 104-112.

Al-Khuli, M. A. (1981). Dictionary of Education, English-Arabic. Beirut: Dar el-Ilmi li alMalayin.

Aown, N. M. (2011). A place for informal learning in teaching about religion: The story of an experienced non-Muslim teacher and her learning about Islam. Teaching and Teacher Education, 27(8), 1255-1264.

Arsyad, A. (2010). Bahasa Arab dan Metode Pengajarannya. Cetakan ketiga. Yogyakarta: Pustaka Pelajar.

Boeree, G. (2008). Metode Pembelajaran dan Pengajaran. alih bahasa Abdul Qodir Sholeh. Yogyakarta: Ar-Ruzz Media.

Cronbach, L. J. (1963). Educational Psychology. New York: Harcourt, Brace World.

Gagne, R. M. (1989). Kondisi Belajar dan Teori Pembelajaran. Alih bahasa Munandir. Jakarta: Depdikbud.

Giladi, A. (2014). The Nurture and Protection of Children in Islam: Perspectives from Islamic Sources: Islamic texts command affection, care, and education. Child Abuse \& Neglect, $38(4), 585-592$.

Graham, W. A. (1993). Traditionalism in Islam: an essay in interpretation. Journal of Interdisciplinary History, 23(3), 495.

Hermawan, A. (2011). Metodologi Pembelajaran Bahasa Arab. Bandung: Rosdakarya.

Ismawati, E. (2011). Perencanaan Pegajaran Bahasa, cetakan kedua, (Surakarta, Yuma Pustaka.

Izzan, A. (2011). Metodologi Pembelajaran Bahasa Arab. Cetakan keempat. Bandung: Humaniora.

Moore, M. (1998). Dynamic Optism, and Extropian Cognitive-Emotional Virtue.

Mourad, M., \& El Karanshawy, H. (2013). Branding Islamic studies: exploratory study in the Middle East. Journal of Islamic Marketing, 4(2), 150-162.

Roslan Mohd Nor, M., \& Malim, M. (2014). Revisiting Islamic education: the case of Indonesia. Journal for Multicultural Education, 8(4), 261-276.

Thorndike, R. M., dan Chunningham, G. K. (1986). Measurement and Evaluation in Psychology and Education. New York: McMillan.

Wanlabeh, A. O. N. (2012). Teachers' perpectives on leadership practices and motivation in Islamic pricate schools, Southern Thailand. Asian Education and Development Studies, $1(3), 237-250$. 
Wekke, I. S. (2012). Amalan pengajaran dan pembelajaran bahasa arab di pesantren immim Makassar, Indonesia. Disertasi. Bangi: Fakulti Pendidikan, Universiti Kebangsaan Malaysia.

Wekke, I. S. (2015). Antara Tradisionalisme dan Kemodernan: Pembelajaran Bahasa Arab Madrasah Minoritas Muslim Papua Barat. Jurnal Peradaban Islam Tsaqafah, 11(2), November 2015, 313-332.

Yamin, M. (2010). Manajemen Mutu Kurikulum Pendidikan. Cetakan kedua. Yogyakarta: Diva Press, 2010.

Yates, S. M. (2000). Student Optimism and Pessimism During the Transition to Co-education. Paper presented at The Australian Association for Research in Education Conference. Sidney, Desember.

Yovita. (2004). Understanding the Barries in Learning Second Language. Tesis Magister. Yogyakarta: Fakultas Psikologi Universitas Gadjah Mada.

Yusuf, M., \& Suardi, I. (2015). Active learning on teaching Arabic for special purpose in Indonesian pesantren. Procedia - Social and Behavioral Sciences, 191, 137-141.

Wekke, I. S. (2013). Islam di Papua Barat: tradisi dan keberagaman. ULUL ALBAB Jurnal Studi Islam, 14(2). 